\title{
Stowo wstępne
}

Trzeba być dobrym jak chleb, położony na stole, z którego każdy może ukroić dla siebie kęs.

brat Albert Chmielowski

Oddajemy do Waszych rąk kolejny numer czasopisma „Pro Musica Sacra”. Znajdziemy w nim artykuły, które dotyczą rocznic obchodzonych w tym roku, a więc: 50-lecia śmierci ks. Idziego Ogiermana Mańskiego SDB, Feliksa Nowowiejskiego, ks. Franciszka Walczyńskiego; kolejno także podejmowane tematy związane z kompozycjami muzyki religijnej, w tym wypadku kompozytorów tej klasy co: Henryk Jan Botor, Paweł Łukaszewski czy ks. Marco Frisina, w tym temacie spoiwem staje się przypomnienie nauczania drogi piękna w muzyce jako właściwej dla niej. Uzupełnieniem są artykuły o muzyce Karola Szymanowskiego, spojrzenie na to, jaka ma być muzyka w klasztorze, oraz spojrzenie na chorał gregoriański w wypadku Topos Romano-frankoński oraz kolejne opracowanie z Archiwum Krakowskiej Kapituły Katedralnej. Dobrze się stało, że mamy tutaj także recenzje płyt $\mathrm{CD}$ wydanych w ostatnim czasie oraz komunikaty z działalności koła studentów muzyki kościelnej; przypomnienie bardzo ważnego spotkania papieża Benedykta XVI z artystami; informacje o XII Dniach Muzyki Kościelnej w Archidiecezji krakowskiej; zestawienie dyplomów z muzyki kościelnej.

Nowością niniejszego numeru jest dział Pasterze Kościoła o muzyce, który rozpoczynamy od wypowiedzi papieża Pawła VI. Wydaje się, że może on się stać dobrym uzupełnieniem całości naszego czasopisma, ufamy przy tym, że będzie on niezwykle twórczą częścią podejmowanych tematów.

Całość tegorocznego czasopisma spaja osoba i działanie wyjątkowego człowieka, który w Krakowie znany jako artysta i posługujący ubogim, po 100-latach od jego śmierci powraca, jako przykład właściwego odniesienia do Boga i do człowieka. Święty brat Albert Chmielowski jest nie tylko patronem tego roku ustanowionym przez Konferencję Episkopatu Polski i Sejm RP, lecz także wyraźnym „światłem na przyszłość”. Bowiem wszelkie dzieła o tyle są trwałe, o ile mają właściwe fundamenty i wynikają z miłości. I w tym kontekście ważne dla nas jest także to, że czasopismo tegoroczne dedykowane zostaje człowiekowi wielkiej kultury 
i wielkiego ducha, miłośnikowi liturgii i rozmiłowanemu w człowieku naszemu Przyjacielowi ks. prof. dr hab. Janowi Józefowi Janickiemu, który jest jak spoiwo naszego Międzyuczelnianego Instytutu Muzyki Kościelnej w Krakowie. Dziękujemy za Twoją dobroć, zrozumienie i wspaniałą współpracę. Przyjmij ten skromny gest wdzięczności od nas, Twoich współpracowników.

ks. dr hab. Robert Tyrała, prof. UPJP II redaktor naczelny PMS

Kraków, 17 czerwca 2017 roku

Wspomnienie św. brata Alberta Chmielowskiego 